\title{
The History of the Asian Association of Endocrine Surgeons
}

\author{
Akira Miyauchi
}

\section{ABSTRACT}

The Asian Association of Endocrine Surgeons (AsAES) was established in 1986, 30 years ago. Its history was never described in detail. This article describes its establishment and development in detail with many memorial pictures. This article was read at the 15th Congress of the AsAES held in Seoul in April 8, 2016.

Keywords: Asian association of endocrine surgeons, Chairman, History, Officers, President.

How to cite this article: Miyauchi A. The History of the Asian Association of Endocrine Surgeons. World J Endoc Surg 2016;8(2):147-155.

\section{Source of support: Nil}

Conflict of interest: None

\section{INTRODUCTION}

Congress President Euy-Young Soh asked me to talk about the history of the Asian Association of Endocrine Surgeons (AsAES). This is a very good time to look back at the history of the AsAES, since this is the 30th anniversary of its establishment.

The AsAES was established in 1986, 30 years ago, and the 1st Congress was held in Tokyo 2 years later, led by President Yoshihide Fujimoto. By the way, the Japanese Association of Endocrine Surgeons was established in 1989, and its 1st Congress was held in Tokyo the same year, also led by President Yoshihide Fujimoto. These two associations were established as a type of "sister associations" to the International Association of Endocrine Surgeons (IAES), which was established in 1979. In Japan, we also have a different society, the Japanese Society of Thyroid Surgery, which started as the Thyroid Surgery Conference in 1968. We have a much longer history.

At the meeting of the IAES in Helsinki in 2013, President Robert Udelsman gave the Peter Heimann Lecture on the origin of the IAES. He said that the IAES owes its

Chairman, Asian Association of Endocrine Surgeons

Department of Surgery, Kuma Hospital, Center for Excellence in Thyroid Care, Kobe, Hyōgo Prefecture, Japan

Corresponding Author: Akira Miyauchi, Chairman, Asian Association of Endocrine Surgeons, Department of Surgery Kuma Hospital, Center for Excellence in Thyroid Care, Kobe Hyōgo Prefecture, Japan, Phone: +81783713645, e-mail: miyauchi@kuma-h.or.jp origin mostly to Peter Heimann, Professor of Surgery, Bergen, Norway. Professor Heimann was a general surgeon with a particular interest in the thyroid gland, and it was his ambition to gather general surgeons interested in the endocrine system into a special group within the Société Internationale de Chirurgie (the SIC), which is now called the International Society of Surgery. In 1978, as he was dying of gastric cancer, Professor Heimann wrote to some of his friends stating his fervent wish that a group of surgeons interested in the endocrine organs should be formed. In response to his letter, on September 4, 1979, a group met in a room of the SIC Congress in San Francisco and selected a President, Selwyn Taylor. Yoshihide Fujimoto from Tokyo and Thomas S. Reeve from Sydney also attended this meeting, representing Asia and the Oceania region respectively.

Thus, the first meeting of the IAES was held in 1979 in San Francisco, and an IAES meeting has been held every 2 years since then. The second meeting was held in Montreux, Switzerland in 1981. My mentor Shinichiro Takai took me to that meeting, and I have attended every meeting of the IAES since that gathering. The 4th meeting was held in Paris, led by Per-Orla Granberg. During the meeting, Professor Fujimoto was elected as President-elect to hold the meeting 4 years later. The 5 th meeting was held in Sydney, led by Thomas S. Reeve, and the 6th meeting was held in 1989 in Toronto and led by Yoshihide Fujimoto. Figure 1 is a picture taken at the 5 th meeting of the IAES

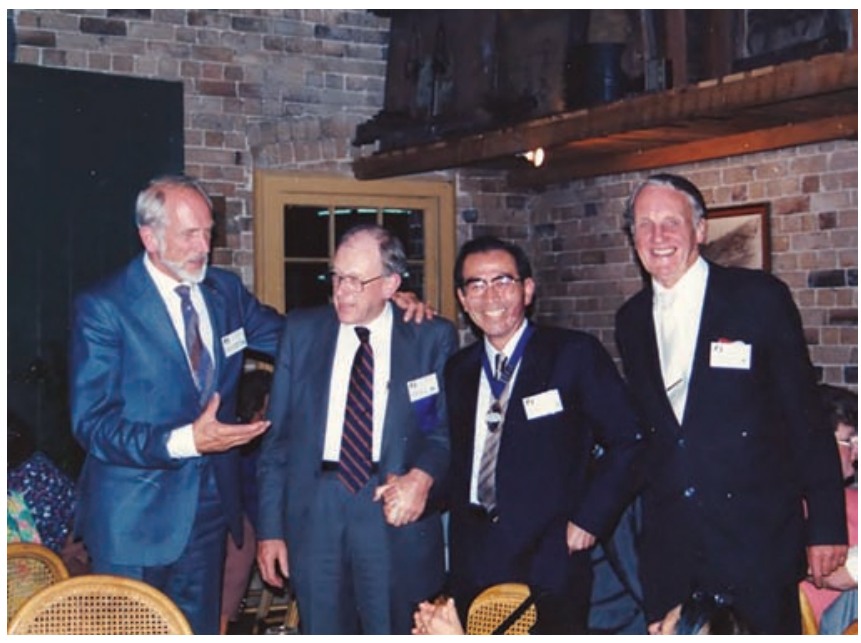

Fig. 1: President Reeve has just handed over his presidential medal to next-President Fujimoto at the IAES meeting in Sydney in 1987 


\section{THE FIRST CONGRESS OF ASIAN ASSOCIATION OF ENDOCRINE SURGEONS (AsAES)}

Tokyo, Japan July 23 and 24, 1988

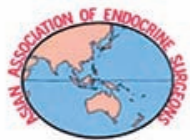

ANNOUNCEMENT AND REGISTRATION FORM

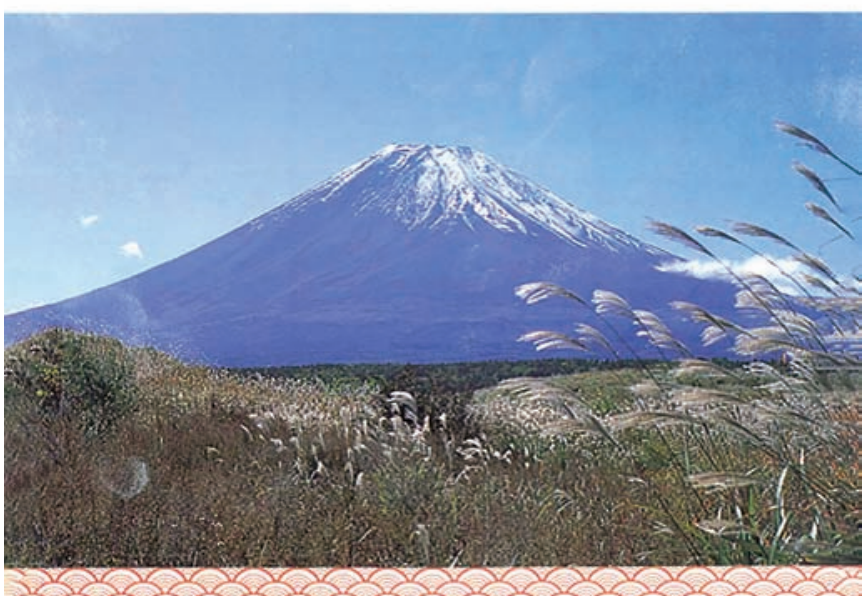

Fig. 2: The first circular on the 1st Congress of the AsAES

in 1987 in Sydney. President Reeve has just handed over his presidential medal to next-President Fujimoto.

Professor Fujimoto wanted to create similar associations in Asia and also in Japan, so he distributed an announcement about the 1st Congress of the AsAES (Fig. 2). He wrote that it was a great pleasure for him as President of the IAES to address all about a new organization, the AsAES (Fig. 3). He recognized that the meetings of the IAES provide good opportunities for mutual understanding and friendship. He noted that familiarity with clinical endocrinology is very important for surgeons and that surgeons must play a significant role in the treatment of diseases of the endocrine organs, such as the thyroid, parathyroid, adrenal, and endocrine pancreas. He also proposed that even simple comparisons of the same diseases between different countries could be very important.

The 1st Congress of the AsAES was held in 1988 in Tokyo, led by President Yoshihide Fujimoto (Fig. 4). Figure 5 shows the first page of the abstract book and my name can be seen. I reported on acute suppurative thyroiditis-pyriform sinus fistula syndrome. A very important person, Cheong-Soo Park from Seoul can also be seen here. He reported on lateral neck mass as an initial manifestation of thyroid carcinoma. My mentor Shinichiro Takai gave a talk on the surgical manage-

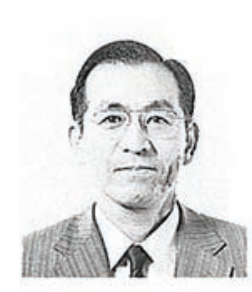

Dear Colleague:

It is the utmost pleasure for me, as the president of International Association of Findocrine Surgeons (IAES), to address you about a new organization of Asian Association of Endocrine Surgeons (ASAES) and having the lirst mecting of the society.

As you know, the congress of IAES, started in 1979, has been held every other year and there has been a great advance in both quantity and quality of presentations during the past 8 years. The meetings of the Association have provided good opportunities for mutual understanding and friendship.

Aside from IAES Society, endocrine surgeons in Scandinavian countries. North and South America. England. Germany and Greece have their own Associations, and recently Mediterranean Society is under consideration.

Many conferences on endocrinology are held every year, and many papers are published. However, most of those contributions are concerned with experimental or fundamental aspects of endocrinology. I believe that, at least for the present, what Asia needs is Clinical Endocrinology and surgeons must play a great role in the treatment of diseases of endocrine organs, such as the thyroid, parathyroid, adrenal, endocrine pancreas and so on. 1 also believe that, for example, even a simple comparison of a disease between two different Asian countries may propose a clue to new insights into better methods of treatment.

I cordially hope that the first AsAES meeting will add further stimulation to the future studies in endocrine surgery in Asia.

I look forward to your active participation in the Congress in July, 1988.

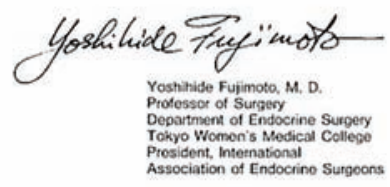

Fig. 3: The greetings in the first circular by President Fujimoto

ment of multiple endocrine neoplasia type 2. Additional important names, Chen-Hsen Lee from Taipei and Shiro Noguchi from Beppu, Japan can also be found.

The 2nd Congress was held 2 years later in Kurashiki, Japan, led by President Tanekazu Harada (Fig. 6). The 3rd Congress was held in 1992 in Taichung, Taiwan, when Dr. Fang-Ku P'eng was President (Fig. 7). Beijing, China was the site of the 4th Congress held in 1994, with Presi-

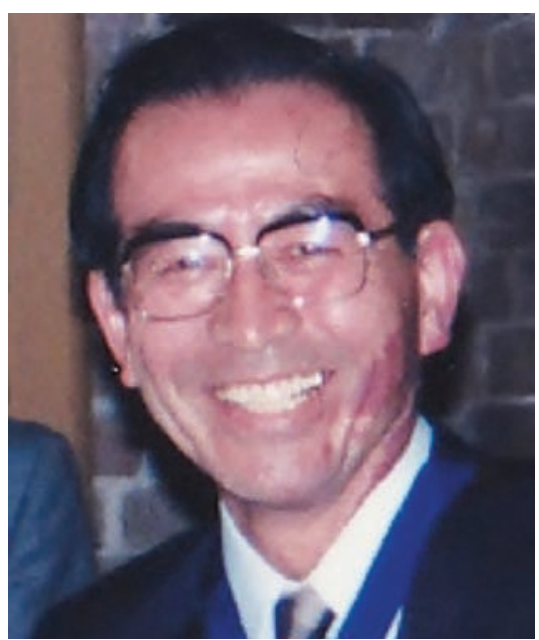

Fig. 4: The 1st Congress of the AsAES was held in 1988 in Tokyo, led by President Yoshihide Fujimoto 
JULY 24, 1988, SUNDAY

8:30 a.m. Registration - Tokyo Women's Medical College, Yayoi Memorial Hall

9:00 a.m. Scientific Meeting B-2 Chairmen: A.Gabriel, MBBS (Cey), FRCS(Eng),
FRCS (Edin), (Maharagama) and Futoshi Iida,M.D. (Matsumoto)

9:00 a.m. \#6 TSH-SUPPRESSIVE THERAPY IN SOLITARY BENIGN THYROID NODULES

P.Cheung, J.Boey and J.Lee

Dept. of Surgery, University of Hong Kong, Hong Kong

9:15 a.m. \#7 ACUTE SUPPURATIVE THYROIDITIS

A.Miyauchi, F.Matsuzuka, S.Takai and K.Kuma Dept. of Surgery, Kagawa Medical School, Kagawa; Kuma Hospital, Kobe; and Dept. of Surgery, Osaka University Medical School, Osaka

9:30 a.m. $\$ 8$ LATERAL NECK MASS AS INITIAL MANIFESTATION OF THE THYROID CARCINOMA

Dept. of Surgery, Yonsei University college of Medicine, Seoul

$9: 45$ a $\mathrm{m}$ \# 9 SURGICAL MANAGEMENT OF MULTIPLE ENDOCRINE NEOPLASIA TYPE 2 (MEN 2)

S.Takai, T.Kobayashi, A.Miyauchi, T.Higashi,

Y.Kurita and T.Mor

The 2nd Dept. of Surgery, Osaka University Medical School, Osaka

10:00 a.m. Scientific Meeting B-3

Chairmen: Chen-Hsen Lee, M.D. (Taipei) and Shiro Noguchi, M.D. (Beppu)

Fig. 5: This is the first page of the abstract book of the 1st Congress of the AsAES

\section{The 3rd Congress}

Asian Association

of

Endocrine Surgeons

INVITATION PROGRAM

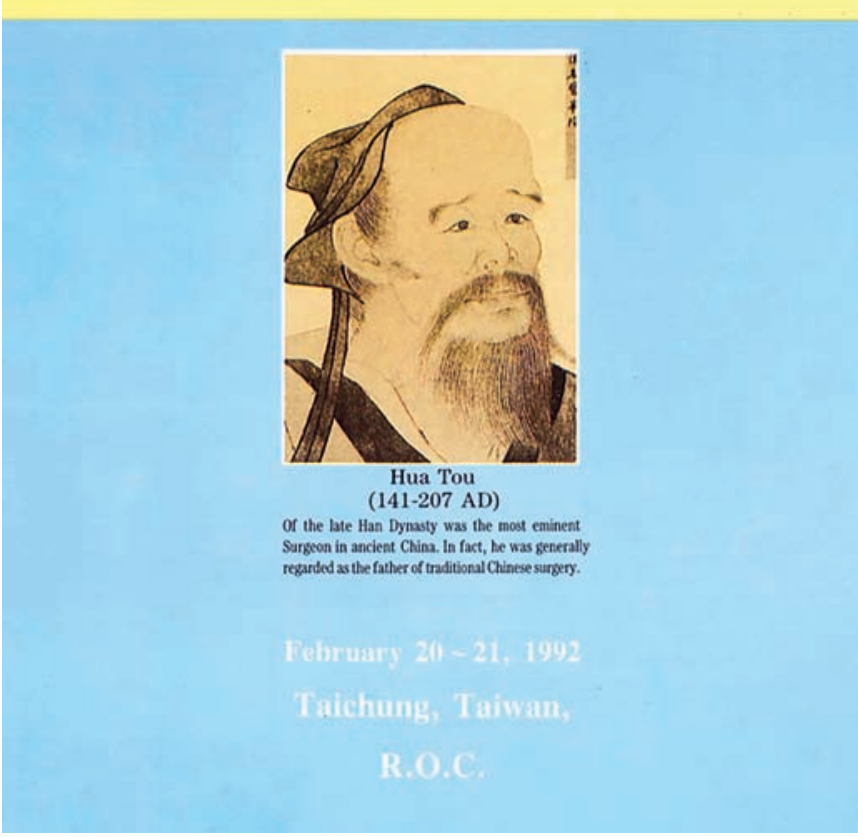

Fig. 7: The 3rd Congress was held in 1992 in Taichung, Taiwan, when Dr. Fang-Ku P'eng was President

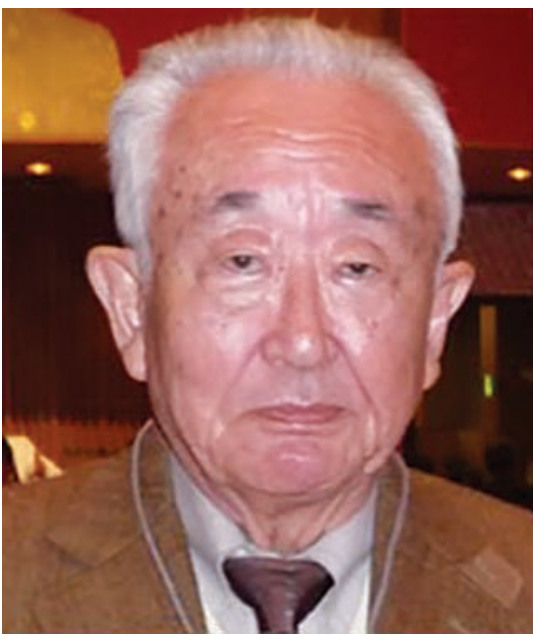

Fig. 6: The 2nd Congress was held in 1980 in Kurashiki, Japan, led by President Tanekazu Harada

dent Zhu Yu in charge (Fig. 8). During that Congress, as an excursion, we greatly enjoyed the unique scenery of the Forbidden City, the old Chinese Palace, where I met many Korean doctors (Fig. 9, Dr. Cheong-Soo Park can be seen). Since then, he and I have become good friends. I also met Ron Nishiyama. He was a very famous endocrine pathologist and a good friend of Norman Thompson. Freda Meah became Congress President 4 years later.

\section{THE 4TH CONGRESS OF THE ASIAN ASSOCIATION OF ENDOCRINE SURGEONS}

\section{May 3-4,1994 Beijing,China}

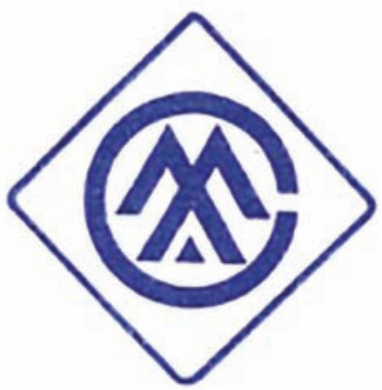

\section{Chinese Society of Surgery \\ Chinese Medical Association}

Fig. 8: Beijing, China was the site of the 4th Congress held in 1994, with President Zhu Yu in charge 


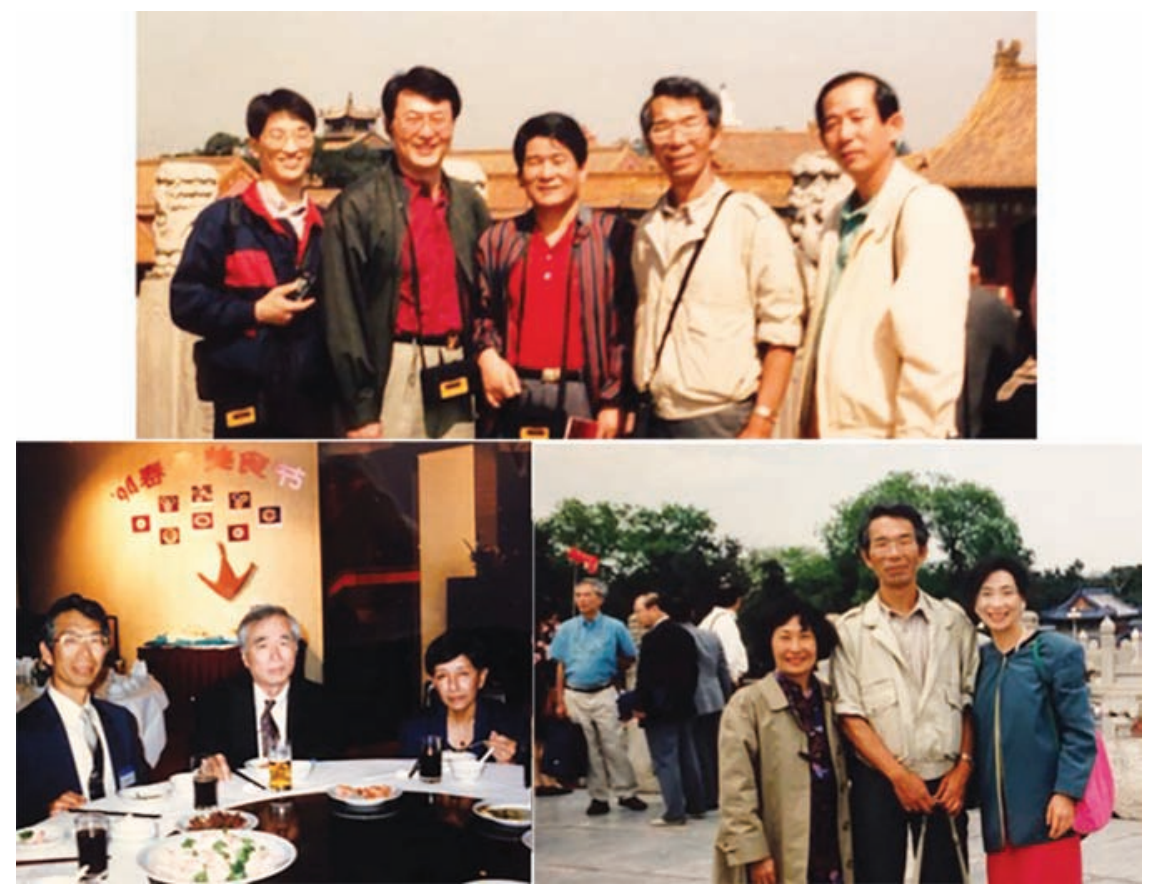

Fig. 9: Picture taken during the 4th Congress

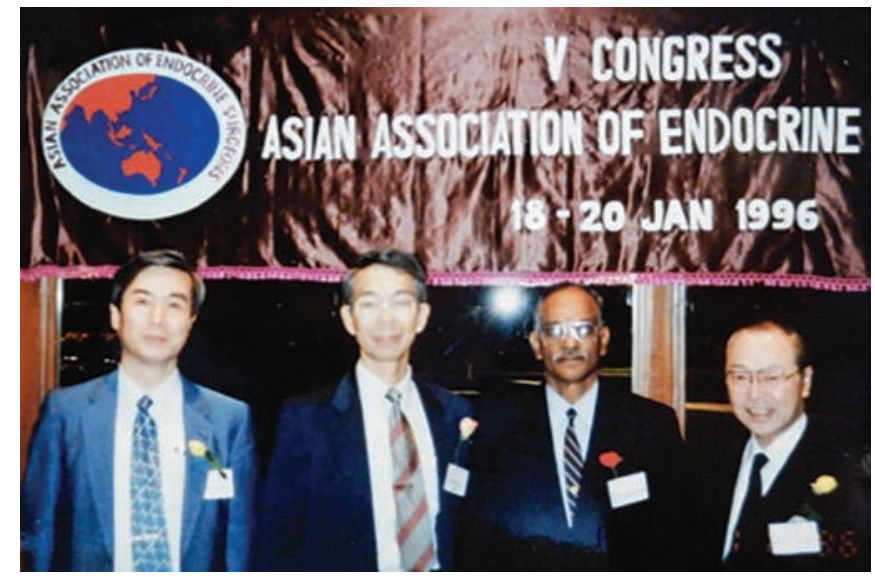

Fig. 10: The 5th Congress was held in 1996 in Hyderabad, India, led by President Lakshmana Rao (second from right)

The 5th Congress was held in 1996 in Hyderabad, India, led by President Lakshmana Rao (Fig. 10). I attended this Congress with my mentor Shinichiro Takai, but unfortunately he passed away last year. Kuala Lumpur, Malaysia hosted the 6th Congress held in 1998; it was led by President Freda Meah (Fig. 11). The 7th Congress was in 2000 in Adelaide, Australia. President Robert Parkyn led this Congress (Fig. 12). Many familiar faces, Dr. Chang, Dr. Lee, and Dr. Kang, can be seen (Fig. 12). After the 7th Congress, President Parkyn organized a satellite meeting on Kangaroo Island. Many delegates from many countries joined the meeting (Fig. 13). We discussed a wide variety of endocrine surgery issues, including the education of young surgeons. On a picnic we enjoyed the unique scenery of Australia and also some fine Australian wine. Many people were looking upward.
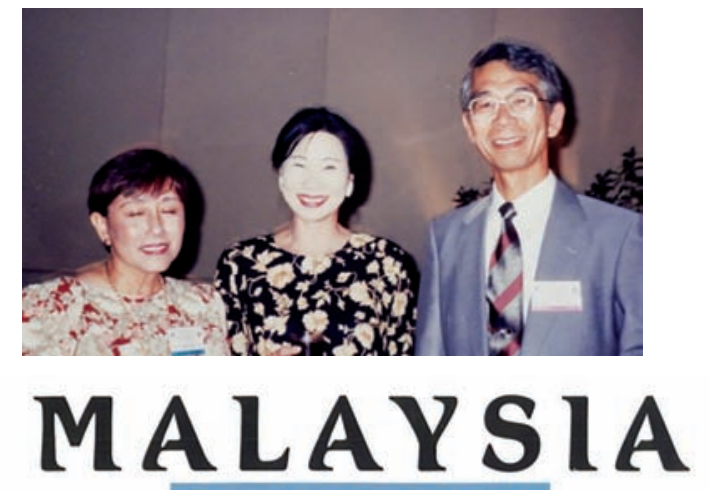

FASCINATING DESTINATION

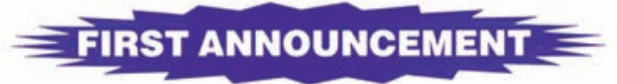

\section{6th BIENNIAL CONGRESS OF THE ASIAN ASSOCIATION OF ENDOCRINE SURGEONS}

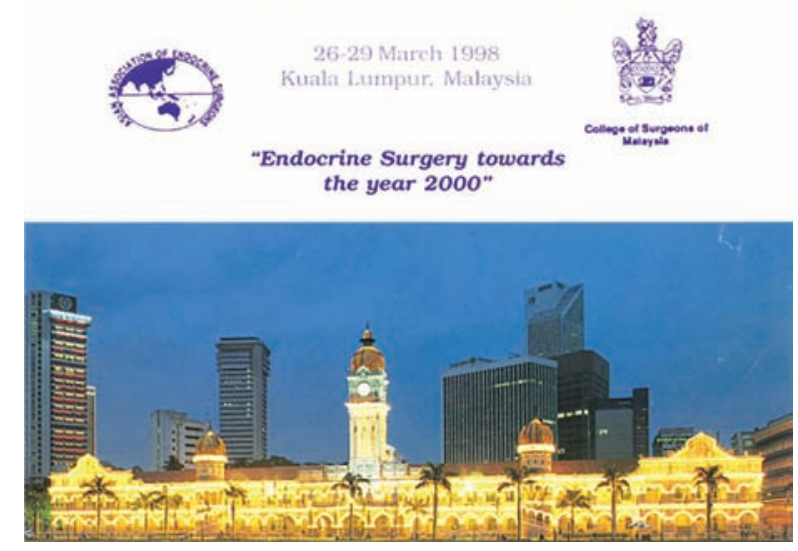

Fig. 11: Kuala Lumpur, Malaysia hosted the 6th Congress held in 1998; it was led by President Freda Meah (left) 


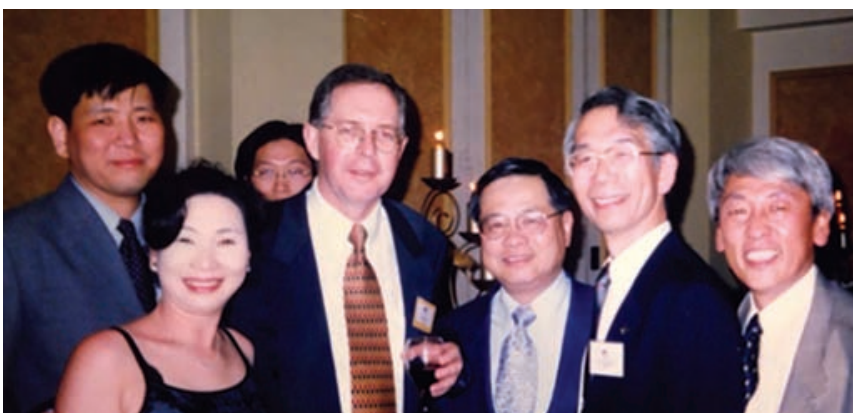

Fig. 12: The 7th Congress was held in 2000 in Adelaide, Australia, led by President Robert Parkyn (third from left)

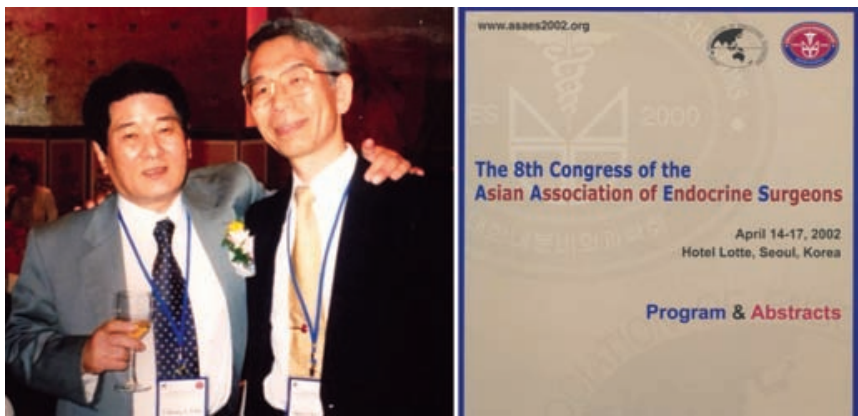

Fig. 14: The 8th Congress was held in 2002 in Seoul, Korea, led by President Cheong-Soo Park (left)

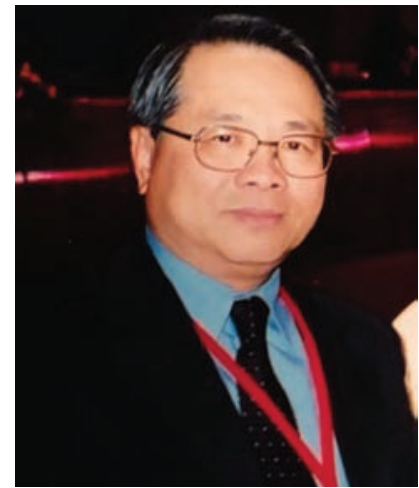

Fig. 15: The 9th Congress in 2004 was held in Taipei, Taiwan and was led by President Chen-Hsen Lee

Can you guess why? Well, they were looking at koalas. Many koala bears were in the trees.

The 8th Congress was held in 2002 in Seoul, Korea, led by President Cheong-Soo Park. It was 14 years ago (Fig. 14). The 9th Congress in 2004 was held in Taipei, Taiwan and was led by President Chen-Hsen Lee (Fig. 15). He was able to secure the attendance of many well-known endocrine experts, namely Ron Nishiyama, an endocrine pathologist, Goran Akerstrom from Sweden, Yoshihide Fujimoto from Tokyo, Norman Thompson from Michigan, Masayuki Imamura from Kyoto, and Sir ED Williams from the United Kingdom. Sir Williams was a very famous endocrine pathologist. ChenHsen Lee became the President of the IAES later and served as President at the meeting in Bangkok, Thailand in 2015.

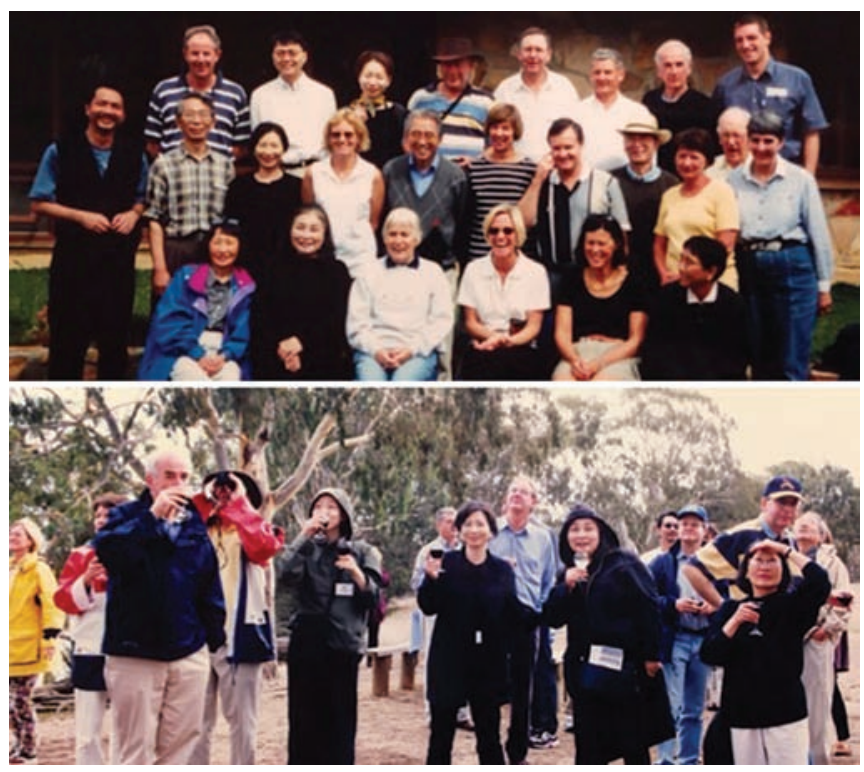

Fig. 13: President Parkyn organized a satellite meeting on Kangaroo Island after the 7th Congress

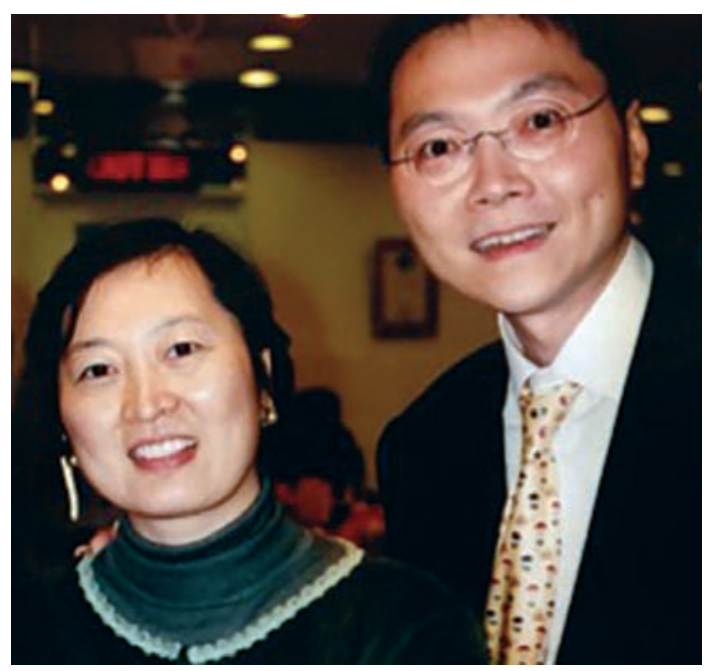

Fig. 16: Hong Kong, China was the location of the 10th Congress in 2006. President Chung-Yau Lo led that Congress (right)

Hong Kong, China was the location of the 10th Congress in 2006. President Chung-Yau Lo led that Congress (Fig. 16). The 11th Congress was held in 2008 in Kota Kinabalu, Sabah, Malaysia and was led by President Hisham Abdullah (Fig. 17). During that Congress, we enjoyed the very beautiful tropical sunset sky and ocean at Kota Kinabalu. Figure 18 was taken from the hotel room of Norman Thompson. He was kind of a "father" in endocrine surgery. Many doctors from Asia and Australia studied under him. Ian Gough, now living in Brisbane, also studied under Norman for some time. Unfortunately, Norman Thompson passed away last year. Tokyo was the site of the 12th Congress, held in 2010 and led by President Kazuo Shimizu (Fig. 19).

Just 4 years ago, President Wei-Keat Cheah led the 13th Congress, in Singapore (Fig. 20). During this Congress, 


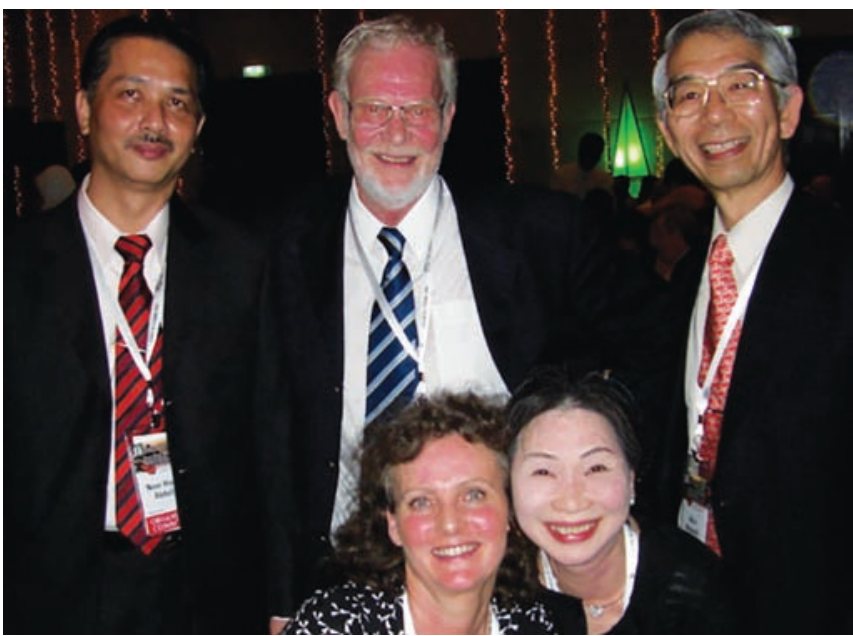

Fig. 17: The 11th Congress was held in 2008 in Kota Kinabalu, Sabah, Malaysia and was led by President Hisham Abdullah (upper left)

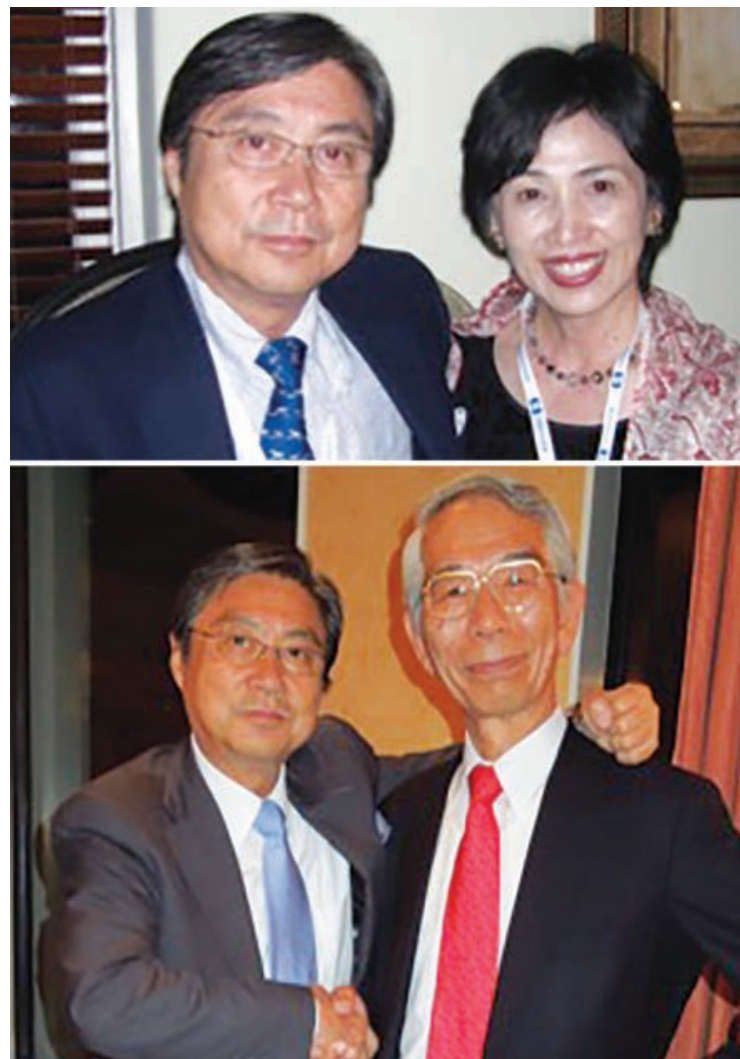

Fig. 19: Tokyo was the site of the 12th Congress, held in 2010 and led by President Kazuo Shimizu (left)

there was a major change in the structure of our Association as an organization. Robert Parkyn, sitting left to President Cheah, made a very significant contribution by creating the constitution of the Association (Fig. 20). The Constitution was created and approved during that Congress, in 2012. It says that the two objectives of the Association shall be (i) to provide a forum for exchanging information and developing new knowledge in the field of endocrine surgery and (ii) to develop a new spirit of friendship among endocrine surgeons in Asia. This Constitution

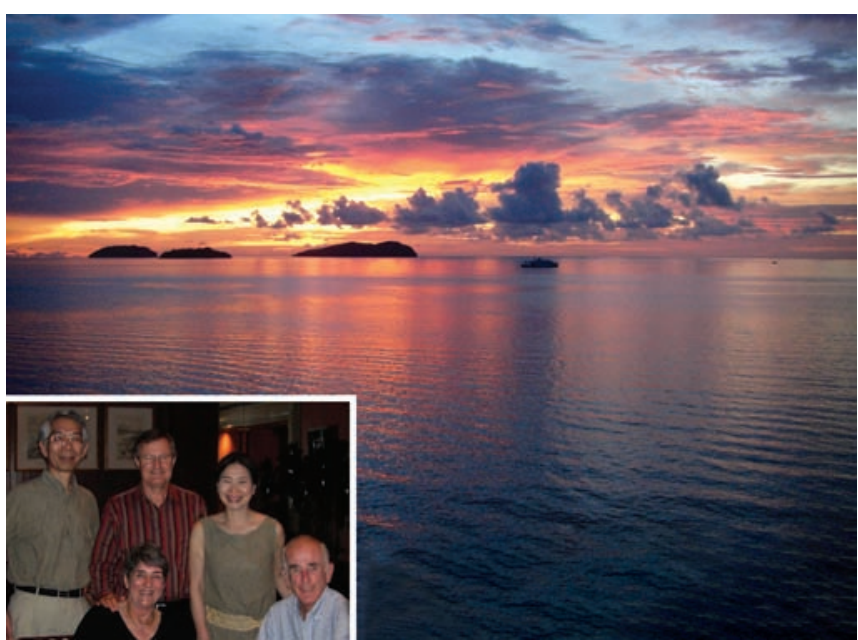

Fig. 18: A very beautiful tropical sunset sky and ocean at Kota Kinabalu taken from the hotel room of Norman Thompson (right)

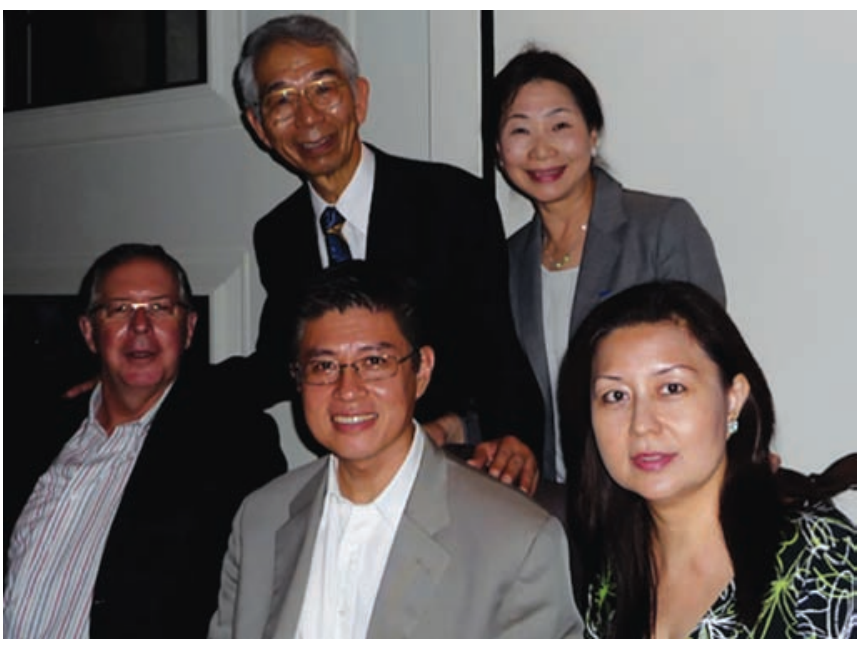

Fig. 20: President Wei-Keat Cheah led the 13th Congress in 2012 in Singapore (center)

defined the roles of the Association's Officers, the Council, and the Advisory Committee. It says that the Officers shall consist of a Chairman, a Congress President, a Congress President-elect, and a Secretary Treasurer. Before this Constitution, we had only a Congress President. The positions of Chairman and Secretary Treasurer were newly created to assure the continuity of the Association. The Council consists of the Officers, the Immediate-past Chairman, the Immediate-past Congress President, and eight Council members. Up to four Council members may be selected by the Chairman. An Advisory Committee of members representing their respective countries can attend the Council Meetings, but they do not have voting rights.

So, the first contingent of Officers were as follows (Fig. 21): I was elected as Chairman. Rohaizak Muhammad of Malaysia was elected as Secretary Treasurer, Ranil Fernando, from Sri Lanka, was elected as Congress President, and Wei-Keat Cheah became the Immediate-past Congress President. I think that the Secretary Treasurer 

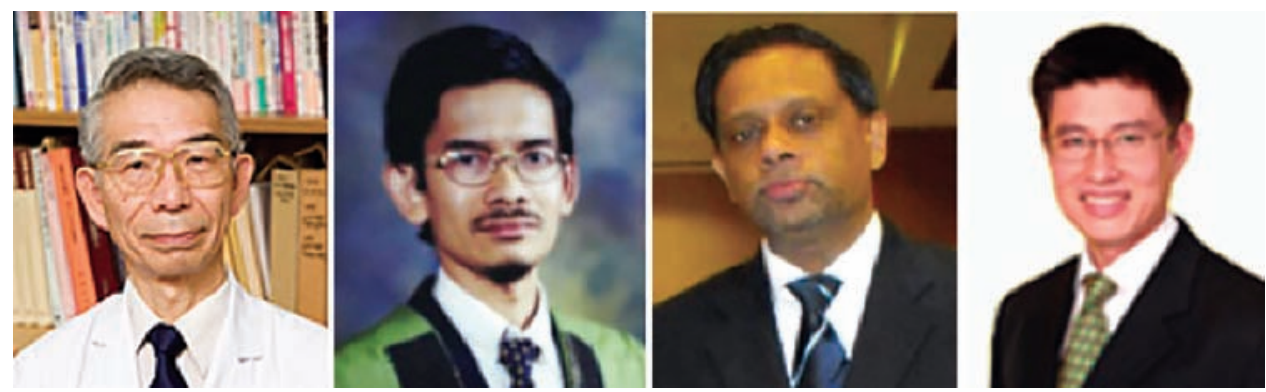

Fig. 21: The first contingent of Officers of the AsAES in 2012

is the key person or the most important person of the Association.

In 2014, the 14th Congress was held in Negombo, Sri Lanka, led by Congress President Ranil Fernando (Fig. 22). This Congress became the first Congress held under the new Constitution. Negombo is a tropical resort area with a wide, beautiful beach with golden sand. The Congress attendees really enjoyed the tropical beach. Look at these people (Fig. 23). How relaxed they are!

The Fujimoto Prize was officially created during this 14th Congress, in part to honor the contribution of Professor Fujimoto to the establishment of our Association (Fig. 24). Shirley Liu, from Hong Kong, became the first Fujimoto Prize winner. The second Fujimoto Prize winner

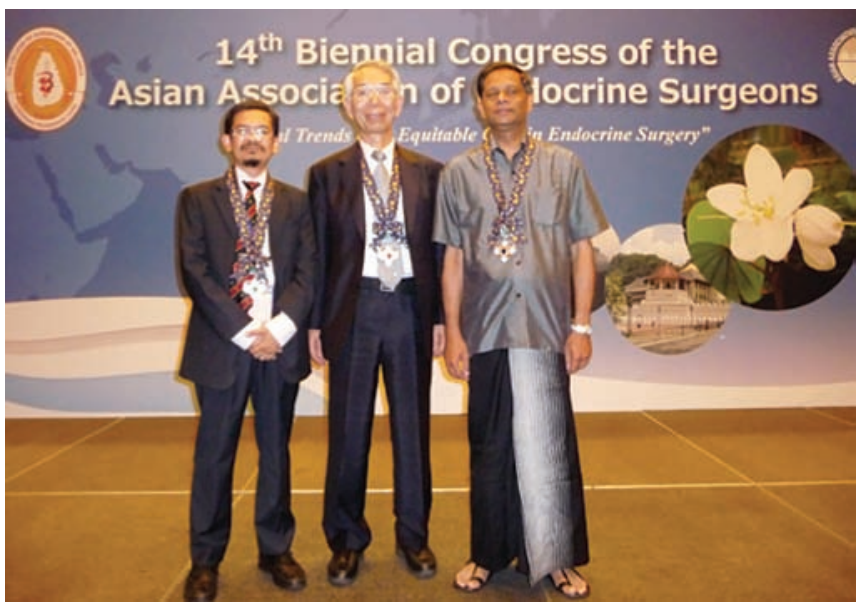

Fig. 22: The 14th Congress was held in Negombo, Sri Lanka in 2014, led by Congress President Ranil Fernando (right) was Yukiko Tsushima, from Nagoya, Japan, and BupWoo Kim, from Seoul, became the third Fujimoto Prize winner. The honorarium for these awardees was donated by the Fujimoto Prize Funding Committee created by members of the Japanese Association of Endocrine Surgeons.

Graph 1 shows the recent trends in the proportions of presentation by major countries, showing that when the Congress was held in Korea, the number of presentations from Korea increased and when it was held in Taiwan, the number of presentations from Taiwan increased, as was also the case with Malaysia and Japan. Clearly, when our Congress was held in a particular country, it attracted local surgeons with an interest in the endocrine field.

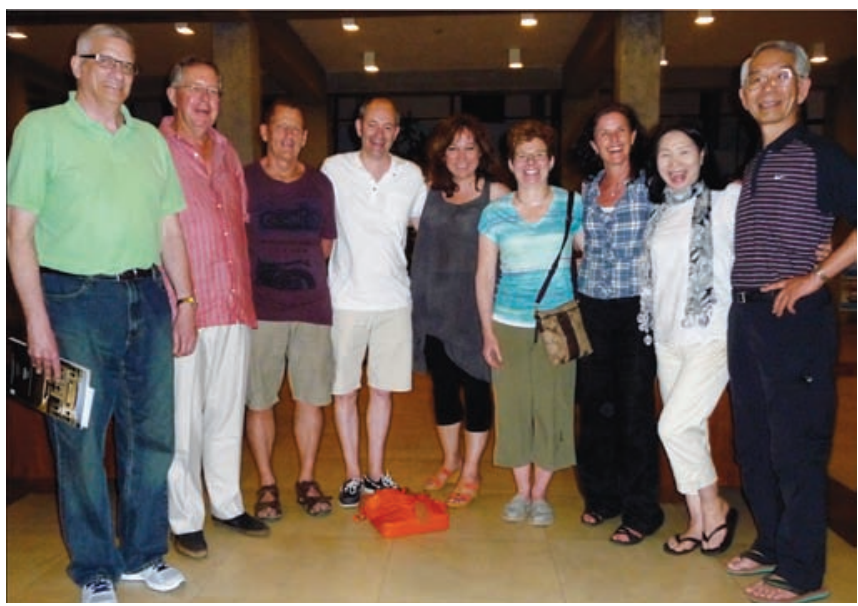

Fig. 23: Very relaxed attendants of the Negombo Congress
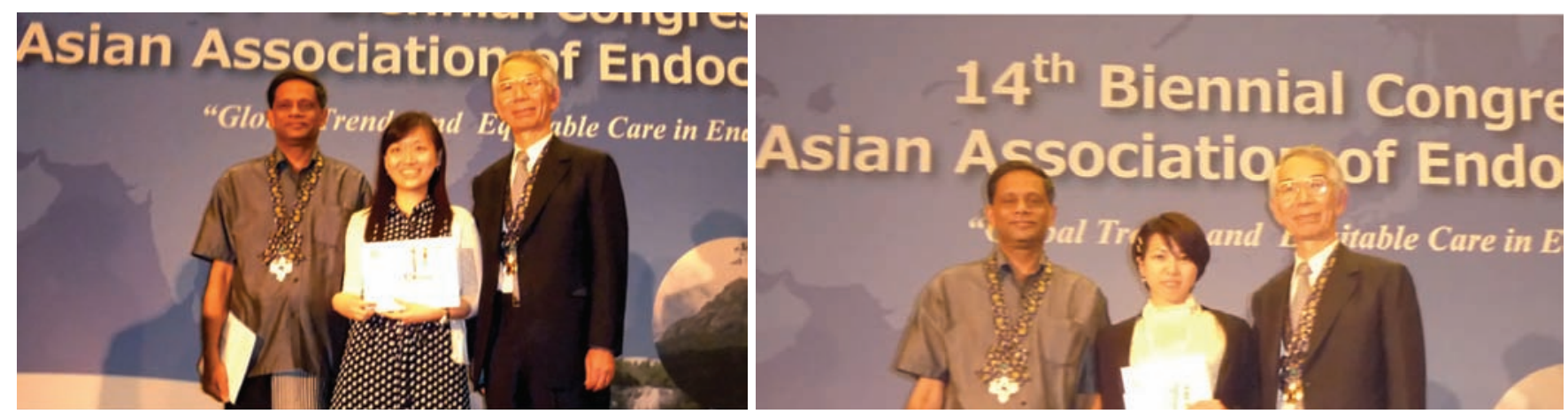

Fig. 24: The first Fujimoto Prize winners 


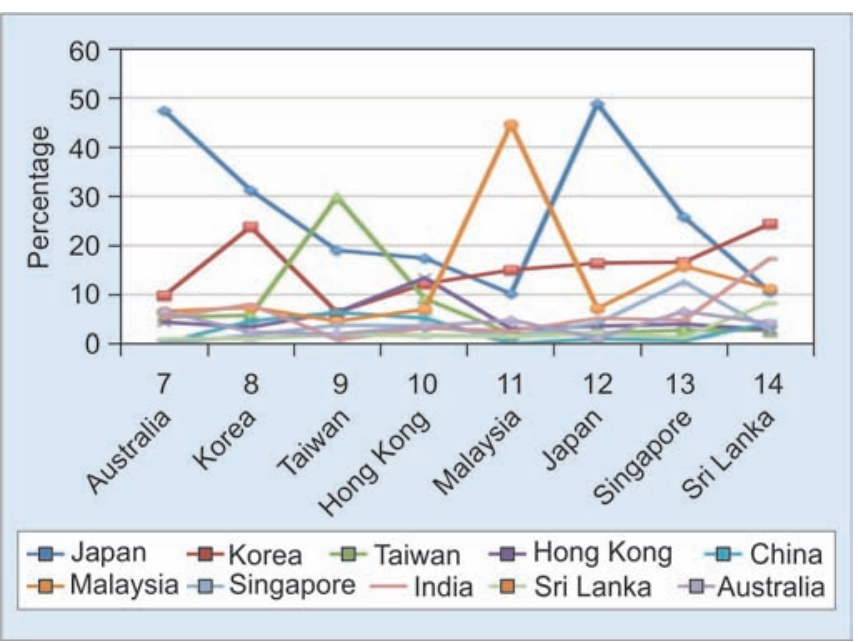

Graph 1: Recent trends in the proportions of presentations by major countries

Dr. Fujimoto proposed that simple comparisons of the same disease among different countries of Asia might be very important. This may be a good example. Figure 25 is courtesy of Dr. Hisham Abdullah, showing goiters in Malaysia. In Japan, we do not observe such big goiters. These examples support the point that Dr. Fujimoto made.

At the last Congress, Professor Euy-Young Soh was elected as Congress President 2016. He addressed the closing ceremony and introduced the Congress 2016 in Seoul (Fig. 26). The present Officers of the Association are Chairman, Secretary Treasurer, Congress President, and

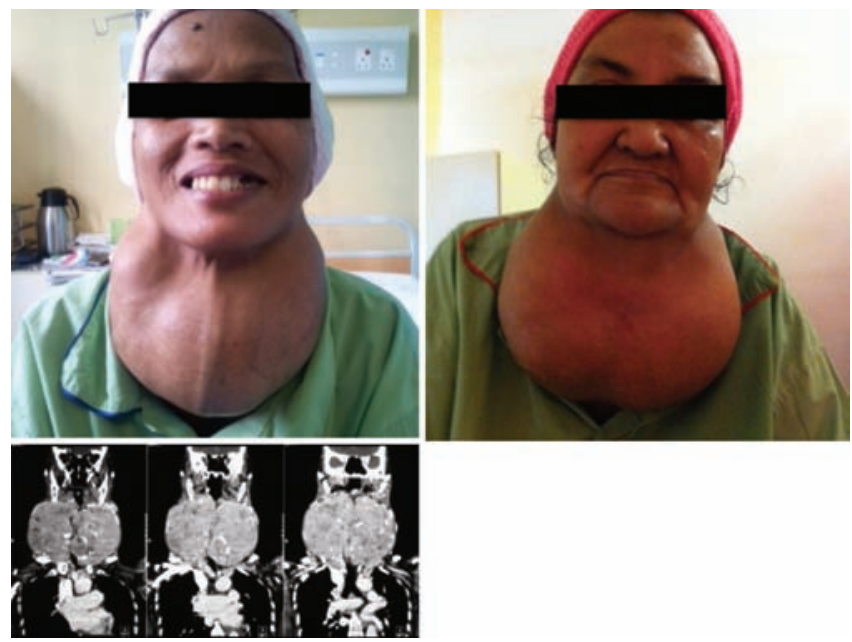

Fig. 25: Goiters in Malaysia (Courtesy: Dr. Hisham Abdullah)

Immediate-past Congress President (Fig. 27).

Our Korean colleagues have been very active in their preparations for the 2016 Congress. They even had a kickoff meeting of the Local Organizing Committee for the AsAES Congress 2016 in Busan on January 10th of 2015 (Fig. 28). I was invited to the kickoff meeting. I was very surprised. So many Korean doctors joining the kickoff meeting can be seen. Therefore, I am very sure that this Congress will be very, very successful.

The 15th Biennial Congress of the AsAES provides a forum for the exchange of information and the

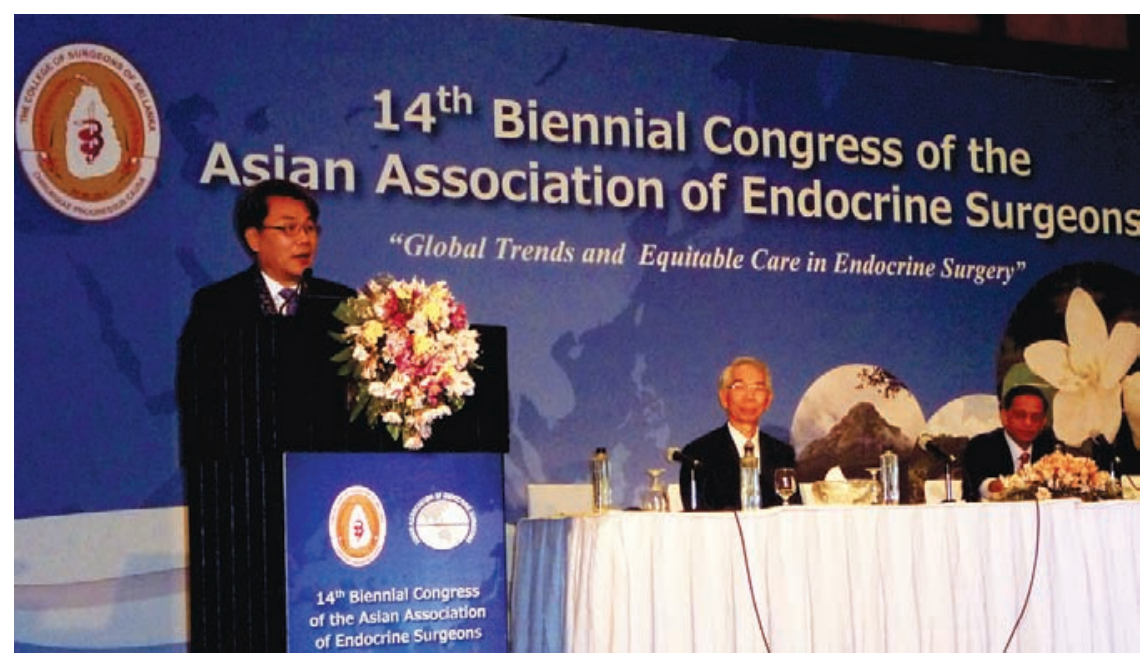

Fig. 26: Professor Euy-Young Soh addressed the closing ceremony and introduced the Congress 2016 in Seoul
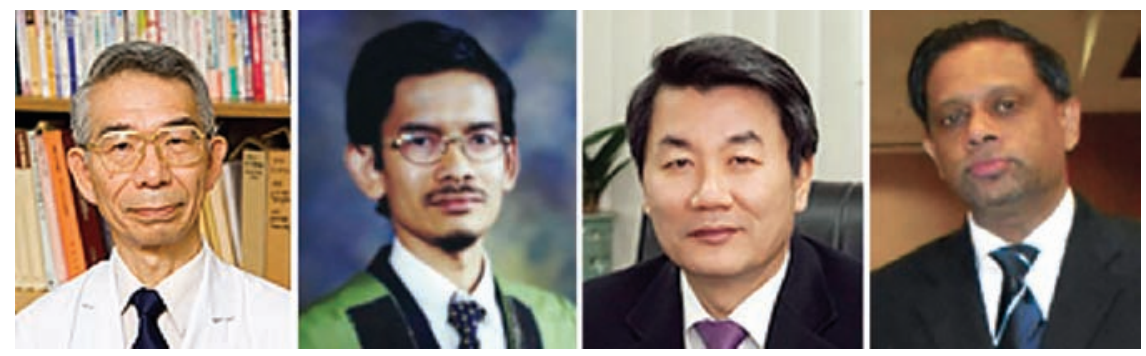

Fig. 27: The present Officers of the AsAES as of April 7, 2016 


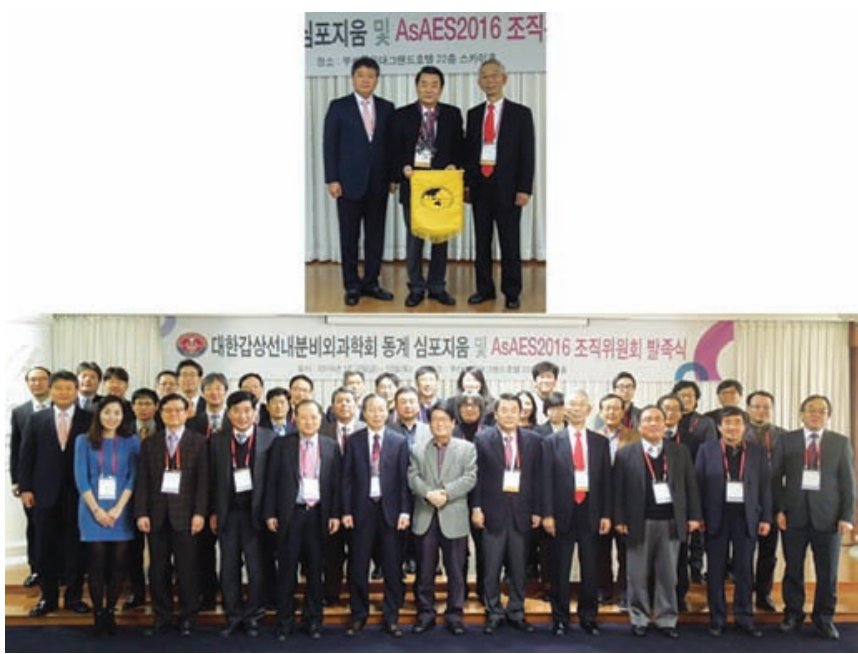

Fig. 28: The kickoff meeting of the Local Organizing Committee for the AsAES Congress 2016 development of new knowledge in the field of endocrine surgery, and it encourages a new spirit of friendship among endocrine surgeons in Asia. I say congratulations to Congress President Euy-Young Soh in advance. I am sure that this Congress will be very successful. Thank you very much.

\section{ACKNOWLEDGMENT}

Professor Yoshihide Fujimoto, the founder and the first president of the Asian Association of Endocrine surgeons passed away on July 23, 2016 at 90 years of age. He was a great surgeon, an intelligent scientist and a fine artist. He was also a very kind teacher to many young endocrine surgeons in Japan and Asia. His contribution to our Association will be succeeded and expanded by the members of the Association. 